УДК 63: 632.3.01/.08

DOI 10.30679/2219-5335-2021-1-67-283-293

ПОДБОР ОПТИМАЛЬНОЙ

МЕТОДИКИ ВЫДЕЛЕНИЯ ДНК

ВОЗБУДИТЕЛЯ ЗОЛОТИСТОГО

ПОЖЕЛТЕНИЯ ВИНОГРАДА

И ПОЧЕРНЕНИЯ КОРЫ

ДЛЯ ВЫЯВЛЕНИЯ ПАТОГЕНА

МЕТОДОМ ПЦР

В РЕАЛЬНОМ ВРЕМЕНИ

Котляр Виктория Константиновна младший научный сотрудник лаборатории сортоизучения и селекции винограда e-mail:mayyyiva@gmail.com

Макаркина Марина Викторовна младший научный сотрудник лаборатории сортоизучения и селекции винограда e-mail:konec_citatu@mail.ru

Степанов Илья Владимирович младший научный сотрудник селекционно-биотехнологической лаборатории

Ильницкая Елена Тарасовна канд. биол. наук

зав. лабораторией сортоизучения

и селекции винограда

e-mail: ilnitskaya79@mail.ru

Федеральное государственное бюджетное научное учреждение «Северо-Кавказский федеральный научный иентр садоводства, виноградарства, виноделия», Краснодар, Россия

Одним из лимитирующих факторов стабильно высоких урожаев с хорошим качеством являются различные болезни культуры. Например, заболевания, вызванные фитоплазмами, могут оказывать серьезное негативное влияние на количество получаемого урожая и его качество, что в дальнейшем может сказаться на качестве винной продукции и получаемой прибыли. Фитоплазмы являются одними из наиболее
UDC 63: 632.3.01/.08

DOI 10.30679/2219-5335-2021-1-67-283-293

\section{SELECTION \\ OF OPTIMAL METHOD \\ OF THE PATHOGEN \\ DNA ISOLATION OF GRAPE \\ FLAYESCENE DOREE \\ AND BOIS NOIR \\ TO IDENTIFY PATHOGEN \\ BY REAL TIME-PCR}

Kotlyar Victoria Konstantinovna
Junior Research Associate
of Laboratory of Cultivar's Study
and Breeding of Grapes
e-mail: mayyyiva@ gmail.com
Makarkina Marina Victorovna
Junior Research Associate
of Laboratory of Cultivar's Study
and Breeding of Grapes
e-mail: konec_citatu@mail.ru

Stepanov Ilya Vladimirovich Junior Research Associate of Breeding and Biotechnology Laboratory

Ilnitskaya Elena Tarasovna Cand. Biol. Sci.

Head of Laboratory of Cultivar's study and Breeding of Grapes

e-mail: ilnitskaya79@mail.ru

Federal State Scientific

Budget Institution

"North-Caucasian Federal

Scientific Center of Horticulture,

Viticulture, Wine-making»,

Krasnodar, Russia

One of the limiting factors of consistently high yields with good quality are various diseases of the crop. For example, diseases caused by phytoplasmas can have a serious negative impact the quantity of the crop and its quality, which can further affect the quality of wine products and profits. Phytoplasmas are one of the most dangerous phytopathogens. On grapes, they are represented by two 
опасных фитопатогенов. На винограде они представлены двумя видами - Candidatus Phytoplasma vitis Flavescence dorée (вызывает золотистое пожелтение винограда) и Candidatus Phytoplasma solani Bois noir (почернение коры). Многие болезни растений, которые, как считается, вызываются фитоплазмами, были описаны до того, как с помощью молекулярногенетических исследований были определены различные группы фитоплазм, вызывающие эти болезни. Теперь можно оценить взаимосвязь между классификацией фитоплазм и конкретными болезнями растений. Золотистое пожелтение листьев является карантинным для РФ и Евросоюза заболеванием и наносит большой урон виноградникам, поэтому быстрая и точная идентификация этого заболевания очень важна. Основным методом идентификации фитоплазм является ПЦР в реальном времени (RT-PCR) со специфическими праймерными системами. Целью нашего исследования было сравнить методы выделения ДНК из растительной ткани, пораженной фитоплазмой, для дальнейшей постановки ПЦР в реальном времени. Данное исследование показало, что образцы, выделенные с помощью коммерческих наборов «АгроДиагностика» и «ЦитоСорб», показывают схожие результаты, в то время как образец, выделенный лабораторным методом на основе использования ЦТАБбуфера, показал более высокие и ранние пики на графике, что имеет значение при детекции малого количества патогена в исследуемом материале и доказывает большую эффективность данного способа выделения.

Ключевые слова: ВИНОГРАД, ФИТОПЛАЗМА, ПЦР В РЕАЛЬНОМ ВРЕМЕНИ, ДИАГНОСТИКА, ЦТАБ species - Candidatus Phytoplasma vitis

Flavescence dorée (causes Golden yellowing of grapes) and Candidatus Phytoplasma solani Bois noir. Many plant diseases that are thought to be caused by phytoplasmas were described before molecular genetic studies identified the various groups of phytoplasmas that cause these diseases. It is now possible to assess the relationship between the classification of phytoplasmas and specific plant diseases. Golden yellowing of leaves is a quarantine disease for the Russian Federation and the European Union and it causes a great damage to vineyards, so quick and accurate identification of this disease is very important. The main method for identifying phytoplasmas is real-time PCR

(RT-PCR) with specific primer systems. The aim of our study was to compare the methods for extracting DNA from plant tissue affected by phytoplasma for further real-time PCR.

This study showed that the samples isolated using the commercial kits "AgroDiagnostics" and "CytoSorb" show the similar results, while the sample isolated by the laboratory method based on the use of CTAB buffer showed higher and earlier peaks on the graph, which is important for detecting a small amount of pathogen in the test material and proves the greater effectiveness of this method of isolation.

Key words: GRAPES, PHYTOPLASMA, REAL-TIME PCR, DIAGNOSTICS, CTAB

Введение. Виноградарство -важная отрасль для экономики Юга России, а Краснодарский край - основной виноградопроизводящий регион в Российской Федерации. К примеру, в 2018 году в Краснодарском крае собрано более 207000 тонн винограда, что составляет 45 \% от общего его урожая в России [1]. Одним из лимитирующих факторов стабильно высоких урожаев с хорошим качеством являются различные болезни культуры. Так, 
Плодоводство и виноградарство Юга России № 67(1), 2021 г.

например, заболевания, вызванные фитоплазмами, могут оказывать серьезное негативное влияние на количество получаемого урожая и его качество, что в дальнейшем может сказаться на качестве винной продукции и на прибыли региона [2].

Фитоплазмы - это биотрофные прокариоты, патогенные для растений, близкие к грамположительным бактериям, в основном передаются насекомыми, принадлежащими к семействам цикадок (Cicadellidae, Cixidae) [3]. Многие болезни растений, которые, как считается, вызываются фитоплазмами, были описаны до того, как с помощью молекулярно-генетических исследований были определены различные группы фитоплазм, вызывающие эти болезни. Теперь можно оценить взаимосвязь между классификацией фитоплазм и конкретными болезнями растений [4].

При заражении фитоплазмами снижение урожая варьирует от незначительного до почти полной его потери на восприимчивых сортах [5-8]. Наиболее вредоносны для винограда два вида фитоплазм: возбудитель золотистого пожелтения Candidatus Phytoplasma vitis и возбудитель почернения древесины Candidatus Phytoplasma solani [9-12].

Значимость ранней точной идентификации связана с тем, что золотистое пожелтение листьев, вызываемое $C$. Ph. vitis Flavescence dorée, является карантинным для РФ и Евросоюза заболеванием, в то время как почернение коры C. Ph. solani Bois noir - к списку карантинных не относится. В самом начале развития болезни очень тяжело визуально определить, какими именно группами фитоплазм оно вызвано.

Материал для закладки насаждений и размножения винограда (подвои, привои и саженцы) часто импортируются из Сербии, Словении и Италии, где золотистое пожелтение винограда присутствует и широко распространено [13]. При идентификации золотистого пожелтения рекомендованной карантинной мерой считается сжигание части площадей виноградника, что влечет за собой значительные экономические потери $[14,15]$. Помимо 
Плодоводство и виноградарство Юга России № 67(1), 2021 г.

этого, по внешним признакам, золотистое пожелтение винограда и почернение коры очень схожи на ранних стадиях развития со скручиванием листьев, вызываемым вирусом, которое находится в списке карантинных заболеваний винограда Евросоюза.

Основное растение-хозяин для возбудителя золотистого пожелтения C. Ph. vitis - виноград европейско-западноазиатской группы, к которому относятся почти все культивируемые сорта. Распространенность фитоплазмозов винограда в районах возделывания культуры может достигать 70-80 \%, а вредоносность превышать 40-80 \% [16]. При зараженности 70 \% виноградники полностью выкорчевывают.

Несмотря на наличие разных фитоплазм типичные симптомы у больных растений, поражённых фитоплазмами, очень схожи между собой и включают в себя: пожелтение листьев (для белых сортов), покраснение (для красных сортов), скручивание листьев, аномальное одревеснение побегов и короткие междоузлия, обесцвечивание листьев, а также пожелтение или покраснение между жилками в зависимости от сорта $[17,18]$.

К фитоплазмам неприменимы многие основополагающие принципы классификации бактерий, основанные на описании морфологии, биофизических и биохимических свойствах. Развитие метода ПЦР позволило провести исследование генома этой группы организмов, определить консервативные гены и разработать классификацию, основанную на генетических критериях. Основными методами идентификации патогена являются следующие молекулярно-генетические методы: «nested»-ПЦР, секвенирование участков генома фитоплазм и ПЦР в реальном времени со специфическими праймерными системами [19].

Целью нашего исследования было сравнение эффективности коммерческих наборов для выделения ДНК патогена из растительной ткани с модифицированным методом экстракции на основе ЦТАБ-буфера (в основе метода лежит лизис клеток с помощью цетилтриметиламмонийбромида) и 
оценка дальнейшего влияния метода выделения ДНК на точность результатов при идентификации фитоплазмы с помощью ПЦР в реальном времени.

Объекты и методы исследований. Для исследования был использован растительный материал сорта винограда Кодрянка, листья которого имели визуальные признаки поражения фитоплазмой. ДНК выделяли из пораженных листьев тремя способами - наборами «АгроДиагностика» (АгроДиагностика, Россия) и ЦитоСорб (ООО «Синтол», Россия), а также модифицированным меодом ЦТАБ [20]. Далее, методом ПЦР в реальном времени с использованием набора реагентов «ФИТОСКРИН» (ООО «Синтол», Россия), предназначенном для дифференциальной диагностики и выявления ДНК фитоплазмы почернения древесины и фитоплазмы золотистого пожелтения винограда, на приборе QuantStudio 5 была проведена реакция амплификации в целях идентификации фитоплазмы в исследуемых образцах.

Обсуждение результатов. При выделении ДНК из растительного материала при помощи коммерческих наборов и методом ЦТАБ были сохранены одинаковые условия в рабочем помещении, что минимизирует влияние дополнительных факторов на экстракцию ДНК. Основным способом оценить результаты при проведении ПЦР в реальном времени является кривая плавления. Она получается путем наблюдения интенсивности флуоресценции продуктов ПЦР (ампликонов) при ступенчатом изменении температуры.

ПЦР в реальном времени показало во всех образцах присутствие патогена $C$. Ph. solani (почернение коры), которое не является карантинным для РФ. Были заметны некоторые различия в интенсивности флюоресценции на графиках, где отчетливо видна разница в пороговых циклах (рис. 1-5). Линия зеленого цвета - внутренний положительный контроль, свидетельствующий о том, что процесс амплификации прошел успешно, синего цвета - свидетельствует о наличии C. Ph. vitis, а красная - о наличии в исследуемом образце C. Ph solani. 
Плодоводство и виноградарство Юга России № 67(1), 2021 г.

Во всех образцах был зафиксирован постепенный рост флуоресценции, свидетельствующий о наработке целевого продукта.

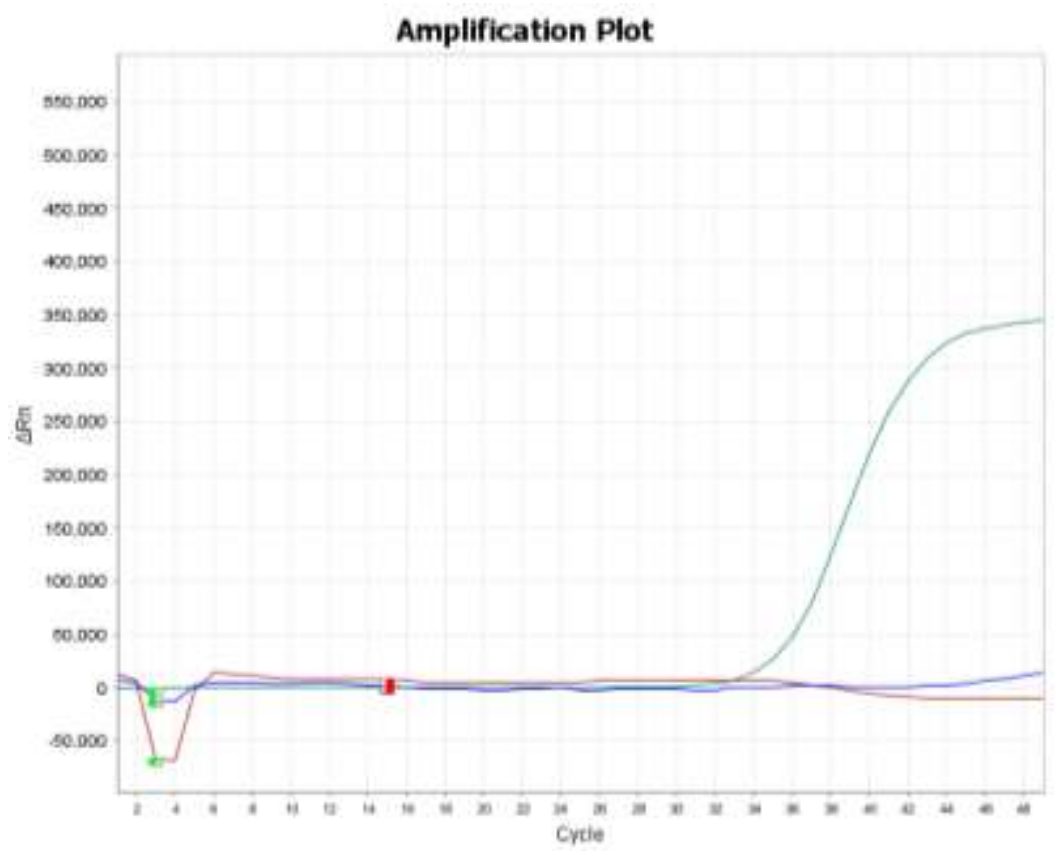

Рис. 1. Отрицательный контроль

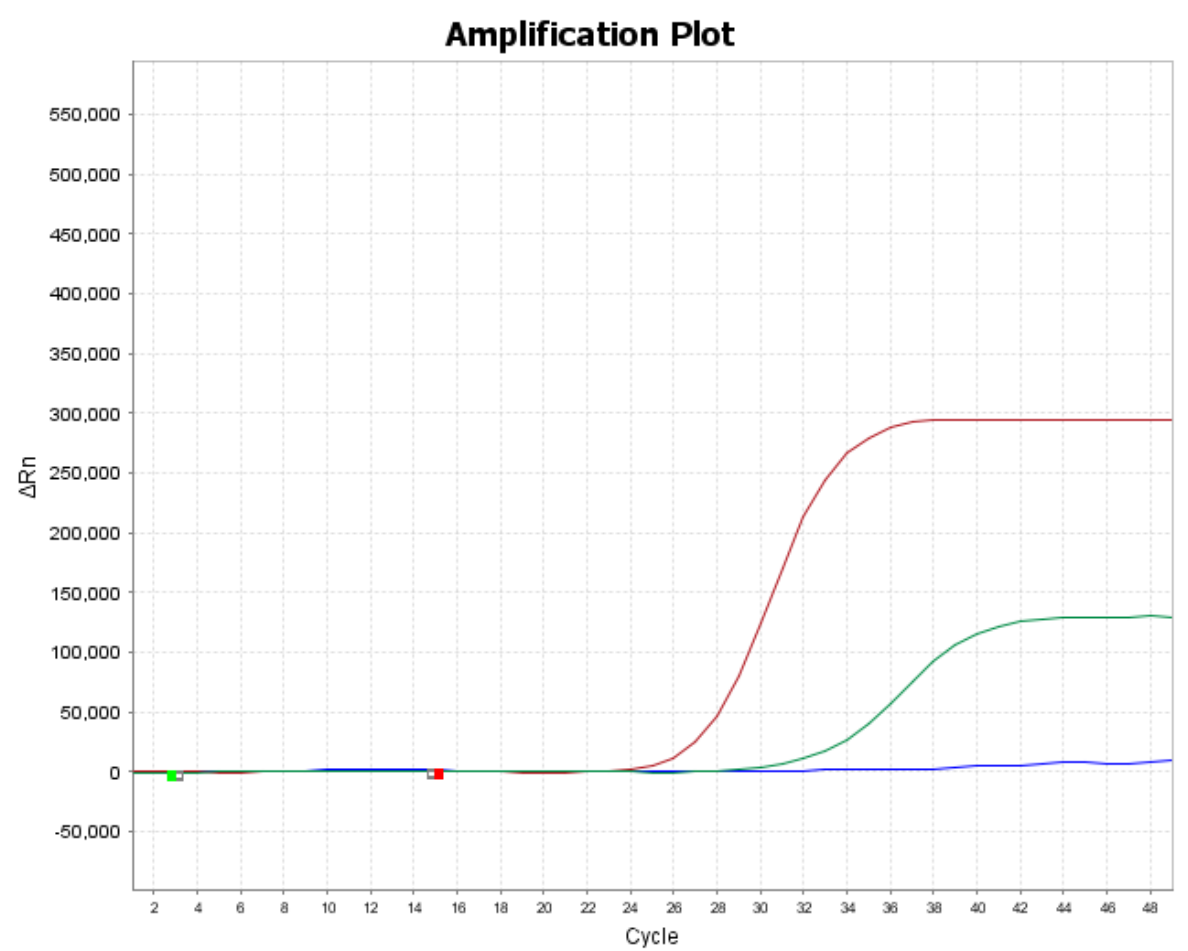

Рис. 2. Визуализация результатов ПЦР в реальном времени образца ДНК, выделенного набором «АгроДиагностика» 
Плодоводство и виноградарство Юга России № 67(1), 2021 г.

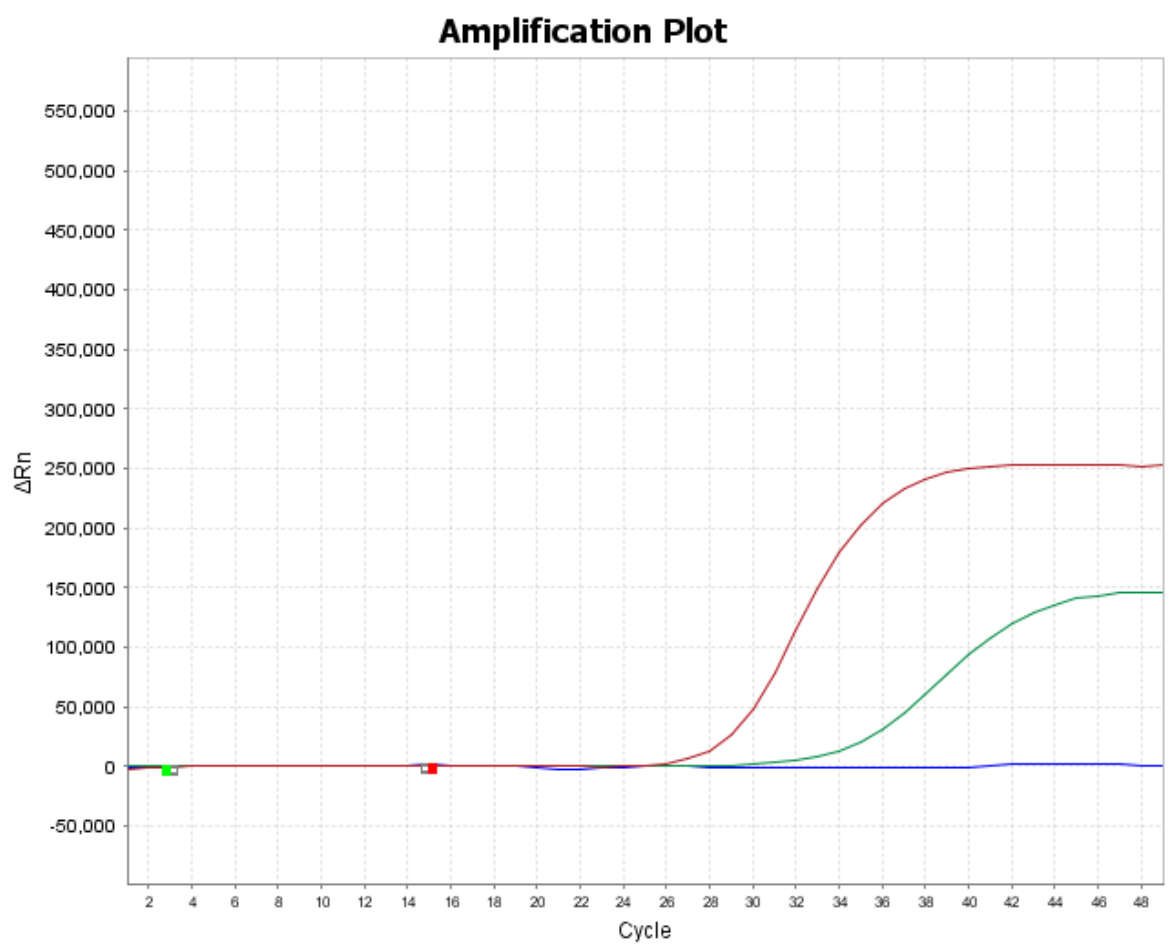

Рис. 3. Визуализация результатов ПЦР в реальном времени образца ДНК, выделенного набором «ЦитоСорб»

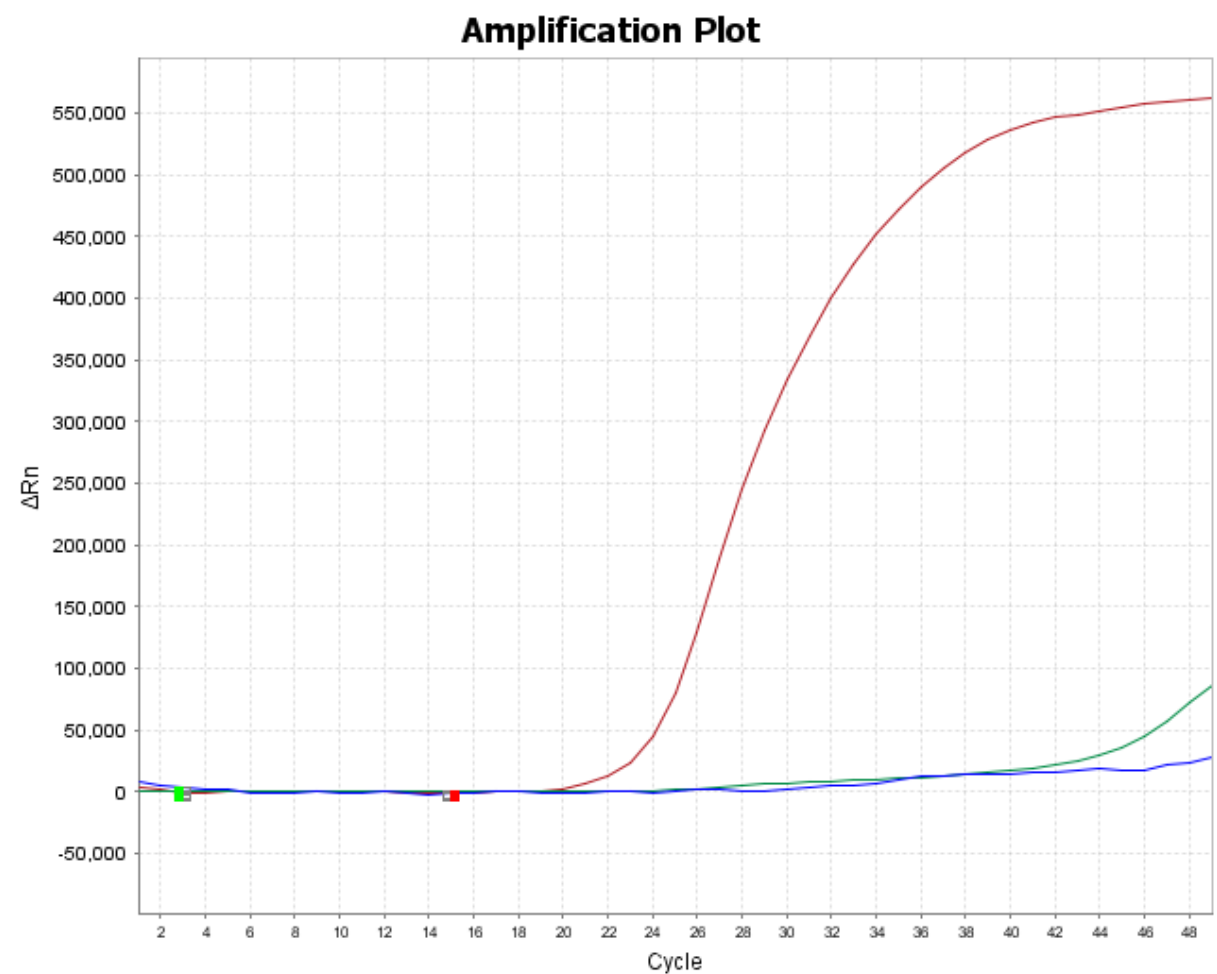

Рис. 4. Визуализация результатов ПЦР в реальном времени образца ДНК, выделенного методом ЦТАБ 


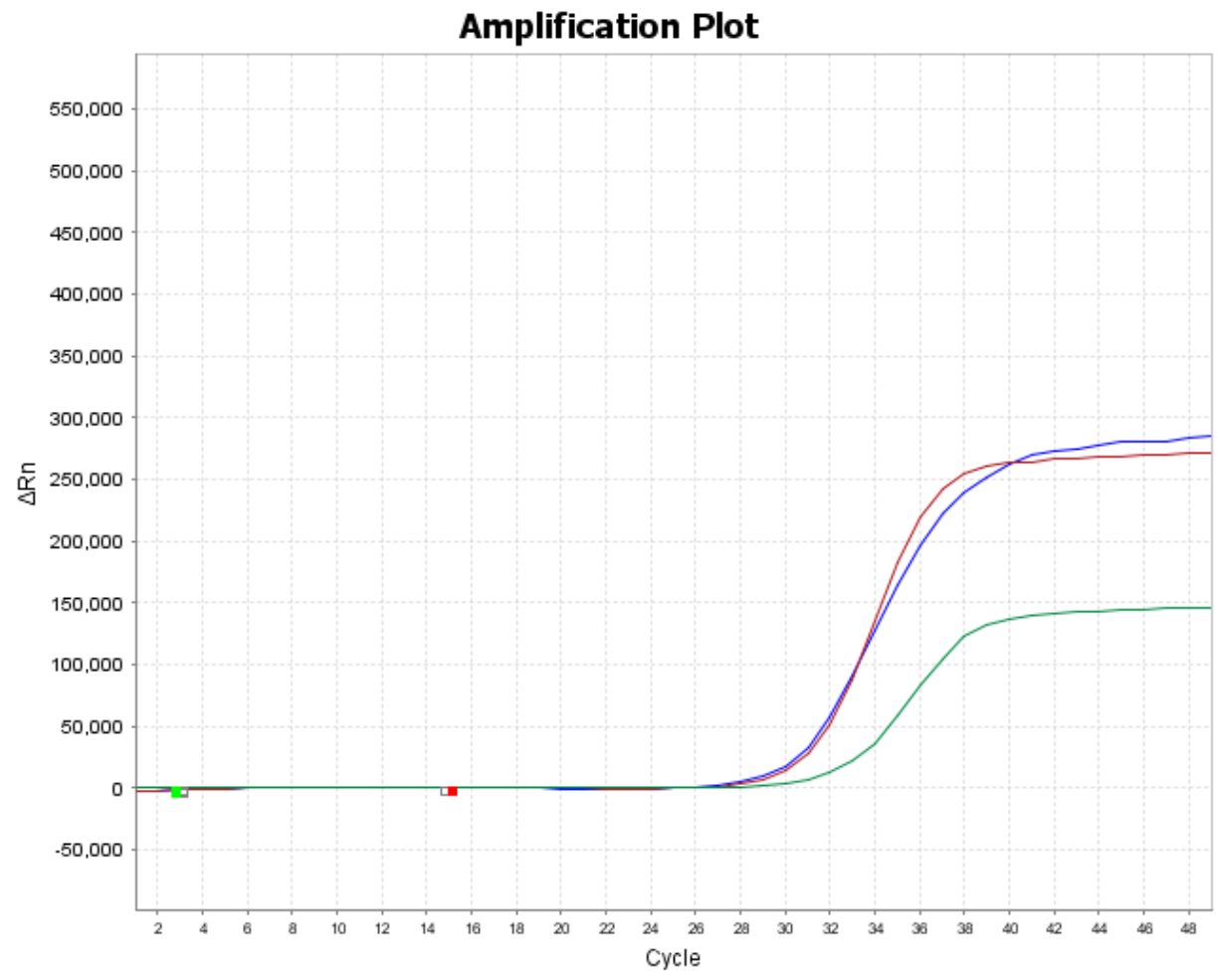

Рис. 5. Положительный контроль

Число пороговых циклов для образца, выделенного с помощью ЦТАБ, составило 20, а для коммерческих наборов «АгроДиагностика» и «ЦитоСорб»- 24 и 26 соответственно.

Ни в одном из образцов не было обнаружено $C$. Ph. vitis несмотря на то, что в образце ДНК, выделенном при помощи метода ЦТАБ, было зафиксировано незначительное накопление продуктов амплификации.

Bbыводы. Данное исследование показало, что образцы, выделенные с помощью наборов «АгроДиагностика» и «ЦитоСорб», проявили следы накопления продуктов амплификации на 24-ом и 26-ом цикле, при этом показав приблизительно одинаковый уровень накопления продукта. В то время как образец, выделенный методом ЦТАБ, показал накопление продукта на 20-ом цикле, помимо этого его концентрация почти в два раза 
Плодоводство и виноградарство Юга России № 67(1), 2021 г.

превышала концентрацию продуктов амплификации, полученных из образцов, выделенных коммерческими наборами, что имеет значение при малом количестве ДНК фитоплазмы в исследуемом материале.

Полученные нами результаты говорят о том, что все исследуемые методы экстракции подходят для дальнейшего использования при постановке ПЦР в реальном времени, однако есть различия в специфике применения. Набор «АгроДиагностика» подходит для ускоренной диагностики патогена, поскольку выделение ДНК с его помощью занимает меньше всего времени среди исследуемых нами методов (от 2 до 3 часов для небольшого количества образцов). Метод экстракции на основе ЦТАБ-буфера обеспечивает высокую чувствительность и точность. Однако, этот метод выделения достаточно продолжительный и занимает около 48-ми часов. Образец, выделенный набором «ЦитоСорб», показал результаты накопления продуктов амплификации, близкие к результатам, полученным набором «Агродиагностика», но на проведение экстракции ДНК было затрачено около 6-ти часов при одинаковом количестве образцов.

\section{Литература}

1. Новости регионов [Электронный ресурс] // Минсельхоз РФ. 2019. URL: http://mcx.ru/press-service/regions/v-krasnodarskom-krae-sobrali-bolee-200-tys-tonnvinograda/ (дата обращения: 19.10.2020).

2. Zambon Y., Canel A., Bertaccini A., Contaldo N. Molecular Diversity of Phytoplasmas Associated with Grapevine Yellows Disease in North-Eastern Italy. Phytopathol. 2018. P. 108: 206. https://doi.org/10.1094/PHYTO-07-17-0253-R

3. Weintraub P.G., Beanland L. Insect vectors of phytoplasmas // Annu. Rev. Entomol. 2006. №51. P. 91-111. https://doi.org/10.1146/annurev.ento.51.110104.151039

4. Davis R.E., Sinclair W.A. Phytoplasma identity and disease etiology // Phytopathology. 1998. Vol. 88. №. 12. P. 1372-1376.

5. Разработка набора реагентов для диагностики фитоплазмы Candidatus Phytoplasma solani - возбудителя почернения древесины методом ПЦР в реальном времени / С.А. Блинова [и др.] // Сельскохозяйственная биология. 2020. Т. 55. №1. С. 194-204.

6. Matyashova G.N., Zaets V.G. Vestnik Rossiiskogo universiteta druzhby narodov. Seriya // Agronomiya i zhivotnovodstvo. 2015. Vol.4 P.7-14.

7. EPPO, Bulletin 7/133 // Generic detection of phytoplasmas // 2018 №48(3): P. 414-424 (doi: 10.1111/epp.12541).

8. Bogoutdinov D.Z., Kastal'eva T.B., Girsova N.V. Tavricheskii vestnik agrarnoi nauki, 2018, 2(14): 15-34 (doi: 10.25637/TVAN.2018.02.02) (in Russ.). 
9. Hren M., Boben L., Rotter A., Kralj P., Gruden K., Ravnikar M. Real-time PCR detection systems for Flavescence dorée and Bois noir phytoplasmas in grapevine: comparison with conventional PCR detection and application in diagnostics // Plant Pathology. 2007. №56(5). P. 785-796. DOI: 10.1111/j.1365-3059.2007.01688.x

10. Angelini E., Bianchi G.L., Filippin L., Morassutti C., Borgo M. A new TaqMan method for the identification of phytoplasmas associated with grapevine yellows by real-time PCR assay // Journal of Microbiological Methods. 2007. №68(3) P. 613-622 DOI: 10.1016/j.mimet.2006.11.015

11. Berger J., Via J.D., Baric S. Development of a TaqMan allelic discrimination assay for the distinction of two major subtypes of the grapevine yellows phytoplasma Bois noir // European Journal of Plant Pathology. 2009. №124(3). P. 521-526 DOI: 10.1007/s10658-0089424-9

12. Choueiri E., Jreijiri F., El Zammar S., Verdin E., Salar P., Danet J.L., Bové J., Garnier M. First report of grapevine "Bois Noir" disease and a new phytoplasma infecting solanaceous plants in Lebanon // Plant Disease. 2002. №86(6). P. 697-697 DOI 10.1094/PDIS.2002.86.6.697A

13. Delic D., Seljak G., Martini M., Ermacora P., Carraro L., Myrta A., Duric G. Surveys for grapevine yellows phytoplasmas in Bosnia and Herzegovina // Bulletin of Insectology. 2007. Vol. 60. №.2. P. 369.

14. EPPO, Bulletin 37 // Diagnostic of Grapevine Flavescence dorée phytoplasma. 2007. - P. 536-542.

15. Иванова Н. А. Карантинные болезни винограда // Защита и карантин растений. 2009. № 2. C. 40-41.

16. Constable F.E. Phytoplasma epidemiology: Grapevines as a model // Phytoplasmas: Genomes, Plant Hosts and Vectors. 2009. P. 188-212 DOI 10.1079/9781845935306.0000

17. Dermastia M., Bertaccini A., Constable F., Mehle N. Grapevine Yellows Diseases and Their Phytoplasma Agents-Biology and Detection // Springer Briefs in Agriculture. 2017. Springer International Publishing AG, Switzerland. P. 134-140

18. Margaria P., Palmano S. Response of the Vitis vinifera L. cv.'Nebbiolo'proteome to Flavescence dorée phytoplasma infection // Proteomics. 2011. Vol.11. №.2. P. 212-224.

19. Белов Д.А., Белов Ю.В., Манойлов В.В. Методика обработки данных при плавлении продуктов полимеразной цепной реакции в реальном времени // Научное приборостроение. 2016. Т.26. № 3. С.10-14

20. Porebski S., Bailey L. G., Baum B. R. Modification of a CTAB DNA extraction protocol for plants containing high polysaccharide and polyphenol components // Plant molecular biology reporter. 1997. Vol.15. №1. P. 8-15.

\section{References}

1. Novosti regionov [Elektronnyj resurs] // Minsel'hoz RF. 2019. URL: http://mcx.ru/press-service/regions/v-krasnodarskom-krae-sobrali-bolee-200-tys-tonn-vinograda/ (data obrashcheniya: 19.10.2020).

2. Zambon Y., Canel A., Bertaccini A., Contaldo N. Molecular Diversity of Phytoplasmas Associated with Grapevine Yellows Disease in North-Eastern Italy. Phytopathol. 2018. P. 108: 206. https://doi.org/10.1094/PHYTO-07-17-0253-R

3. Weintraub P.G., Beanland L. Insect vectors of phytoplasmas // Annu. Rev. Entomol. 2006. №51. P. 91-111. https://doi.org/10.1146/annurev.ento.51.110104.151039

4. Davis R.E., Sinclair W.A. Phytoplasma identity and disease etiology // Phytopathology. 1998. Vol. 88. №. 12. P. 1372-1376. 
5. Razrabotka nabora reagentov dlya diagnostiki fitoplazmy Candidatus Phytoplasma solani - vozbuditelya pocherneniya drevesiny metodom PCR $\mathrm{v}$ real'nom vremeni / S.A. Blinova [i dr.] // Sel'skohozyajstvennaya biologiya. 2020. T. 55. №1. S. 194-204.

6. Matyashova G.N., Zaets V.G. Vestnik Rossiiskogo universiteta druzhby narodov. Seriya // Agronomiya i zhivotnovodstvo. 2015. Vol.4 P.7-14.

7. EPPO, Bulletin 7/133 // Generic detection of phytoplasmas // 2018 №48(3): P. 414-424 (doi: 10.1111/epp.12541).

8. Bogoutdinov D.Z., Kastall'eva T.B., Girsova N.V. Tavricheskii vestnik agrarnoi nauki, 2018, 2(14): 15-34 (doi: 10.25637/TVAN.2018.02.02) (in Russ.).

9. Hren M., Boben L., Rotter A., Kralj P., Gruden K., Ravnikar M. Real-time PCR detection systems for Flavescence dorée and Bois noir phytoplasmas in grapevine: comparison with conventional PCR detection and application in diagnostics // Plant Pathology. 2007. №56(5). P. 785-796. DOI: 10.1111/j.1365-3059.2007.01688.x

10. Angelini E., Bianchi G.L., Filippin L., Morassutti C., Borgo M. A new TaqMan method for the identification of phytoplasmas associated with grapevine yellows by real-time PCR assay // Journal of Microbiological Methods. 2007. №68(3) P. 613-622 DOI: 10.1016/j.mimet.2006.11.015

11. Berger J., Via J.D., Baric S. Development of a TaqMan allelic discrimination assay for the distinction of two major subtypes of the grapevine yellows phytoplasma Bois noir // European Journal of Plant Pathology. 2009. №124(3). P. 521-526 DOI: 10.1007/s10658-008-9424-9

12. Choueiri E., Jreijiri F., El Zammar S., Verdin E., Salar P., Danet J.L., Bové J., Garnier M. First report of grapevine "Bois Noir" disease and a new phytoplasma infecting solanaceous plants in Lebanon // Plant Disease. 2002. №86(6). P. 697-697 DOI 10.1094/PDIS.2002.86.6.697A

13. Delic D., Seljak G., Martini M., Ermacora P., Carraro L., Myrta A., Duric G. Surveys for grapevine yellows phytoplasmas in Bosnia and Herzegovina // Bulletin of Insectology. 2007. Vol. 60. №.2. P. 369.

14. EPPO, Bulletin 37 // Diagnostic of Grapevine Flavescence dorée phytoplasma. 2007. - P. 536-542.

15. Ivanova N. A. Karantinnye bolezni vinograda // Zashchita i karantin rastenij. 2009. № 2. S. 40-41.

16. Constable F.E. Phytoplasma epidemiology: Grapevines as a model // Phytoplasmas: Genomes, Plant Hosts and Vectors. 2009. P. 188-212 DOI 10.1079/9781845935306.0000

17. Dermastia M., Bertaccini A., Constable F., Mehle N. Grapevine Yellows Diseases and Their Phytoplasma Agents-Biology and Detection // Springer Briefs in Agriculture. 2017. Springer International Publishing AG, Switzerland. P. 134-140

18. Margaria P., Palmano S. Response of the Vitis vinifera L. cv. 'Nebbiolo'proteome to Flavescence dorée phytoplasma infection // Proteomics. 2011. Vol.11. №.2. P. 212-224.

19. Belov D.A., Belov Yu.V., Manojlov V.V. Metodika obrabotki dannyh pri plavlenii produktov polimeraznoj cepnoj reakcii v real'nom vremeni // Nauchnoe priborostroenie. 2016. T.26. № 3. S.10-14

20. Porebski S., Bailey L. G., Baum B. R. Modification of a CTAB DNA extraction protocol for plants containing high polysaccharide and polyphenol components // Plant molecular biology reporter. 1997. Vol.15. №1. P. 8-15. 